\title{
Feasibility of Fish and Shellfish Curries Stored in Indigenous Polymer Coated Tin Free Steel Cans
}

\author{
Pushparajan $\mathbf{N}^{*}$, Varadharajan D and Soundarapandian P \\ Faculty of Marine Sciences, Centre of Advanced Study in Marine Biology, Annamalai University, Tamil Nadu, India
}

\begin{abstract}
The study indicated that the suitability of indigenous polymer coated TFS cans for processing at high temperature and pressure. The cook value was found to exhibit an inverse relationship with processing temperature $(p<0.05)$ and was maximum at $115^{\circ} \mathrm{C}$ and minimum at $130^{\circ} \mathrm{C}$. The fish products were acceptable even after 24 months of storage at ambient temperature. The initial overall acceptability score of about 8.75 and it was gradually reduced to around 6.78. It can be seen that the initial pH of fish, shrimp, crab and mussel curries are 5.9, 5.7, 5.6 and 6.0 respectively indicating that it is towards the acidic side. The acidic nature of the product can be attributed to the acidity contributed by the curry ingredients like tomato. During storage, the $\mathrm{pH}$ of the products was found to exhibit a decreasing trend. On the 6th, month of storage, the $\mathrm{pH}$ of fish, shrimp, crab and mussel curries are 5.7,5.6, 5.6 and 5.8 respectively which are significantly lower as compared to initial values. On the 12th month of storage, the $\mathrm{pH}$ of fish, shrimp, crab and mussel curries are 5.6, 5.6, 5.5 and 5.7 respectively. The results of the present experiments showed that the polymer coated TFS cans are suitable for processing fish products. Polymer coated TFS cans was found to withstand all the conditions of thermal processing. The TFS cans which are now available in India can be used for thermal processing of various fish products as a substitute to other packs.
\end{abstract}

Keywords: Fish; Shrimp; Crab; Mussel; Storage; TFS can

\section{Introduction}

Tinplate is light gauge, cold reduced, low-carbon steel sheet or strip, coated on both sides with commercially pure tin. It combines in one material the strength and formability of steel and the corrosion resistance and good appearance of tin. Just under one third of the world's total tin production goes into the manufacture of tinplate, for which food packaging is by far the largest of many diverse applications. Tinplate has been used for preserving food for well over a hundred years and today provides a robust form of packaging, allowing minimization of headspace oxygen and sterilization of the foodstuff within the hermetically sealed can, giving a long, safe, ambient shelf life with no, or minimal, use of preservatives. Worldwide, the total for food packaging is approximately 80,000 million cans. Four metals are commonly used for the packaging of food, steel, aluminium, tin and chromium. Today the opportunity for tin in canning become a great industry, material like tinplate and aluminium have become universally adopted for the manufacture of containers and closures for food and beverage, largely due to several important qualities of containers of these metals. These include their mechanicals strength and resistance to working, low of temperature and ideal surface for decoration and lacquering. Containers are also able to have their temperature, humidity, and gas atmosphere controlled, this is necessary in particular situations such as the transportation of frozen foods, chilled meats and fresh fruits and vegetables.

Canned products enjoy wide acceptance in domestic as well as international markets due to the convenience and ready to eat features. The scope for heat processed food are appears to be bright in future years in developing countries due to urbanization and busy life style. Heat penetration in canned food are influenced by several factors like can materials, size of the container, thickness of the can wall, thermo physical properties of food, filling medium, temperature of process, chemical additives, etc. Rotation of the cans has an effect on the heat penetration characteristic, which reduces process time [1]. The world wide effort that started in the sixties for finding a suitable container for canned products that is free of tin resulted in the birth of Tin Free
Steel in Japan. The chromium coated steel plate has been reviewed as an alternative to tinplate for canning food products by many workers [2-5]. Recently chromium coated steel cans with polymer coating are available in Indian market. In these cans, the chromium coated steel is laminated with Poly Ethylene Terephthalate (PET) which prevents the direct contact between the metallic can and food material packed inside. In the present study feasibility of packing fishery products in indigenes polymer coated tin free cans were tried.

\section{Materials and Methods}

\section{Containers}

Indigenous polymer coated tin free steel can with Easy open ends (EOE): Indigenous Polymer Coated Tin Free Steel cans of size 307X 409 (6 oz capacity manufactured by M/s Amtech Packs, Mysore) were used for the present study (Plate 8). These are 3-piece cans manufactured by (Draw and Redraw) DRD process and are available along with Easy Open Ends (EOE). Both the can and EOE are made from Electrochemically Chromium Coated Steel (ECCS) plate coated with Poly Ethylene Terephthalate (PET) on either side. The plate has a thickness of $0.19 \mathrm{~mm}(0.15 \mathrm{~mm}$ of base steel $+20 \mu$ PET coating on either side). The PET coating substitutes the lacquer coating of conventional tin and aluminium cans is laid as a continuous layer over the chromium coated steel plates by the process of lamination. The EOE is also manufactured from electrochemically chromium coated steel

${ }^{*}$ Corresponding author: Pushparajan N, Faculty of Marine Sciences, Centre of Advanced Study in Marine Biology, Annamalai University, Tamil Nadu, India, E-mail: natanapushpan@gmail.com

Received October 09, 2012; Accepted November 21, 2012; Published November 30, 2012

Citation: Pushparajan N, Varadharajan D, Soundarapandian P (2013) Feasibility of Fish and Shellfish Curries Stored in Indigenous Polymer Coated Tin Free Steel Cans. J Aquac Res Development 4:165 doi:10.4172/2155-9546.1000165

Copyright: (C) 2013 Pushparajan N, et al. This is an open-access article distributed under the terms of the Creative Commons Attribution License, which permits unrestricted use, distribution, and reproduction in any medium, provided the original author and source are credited. 
plates with polymer coating and is provided with unique features like triple fold technology, scoring along the periphery, and pull up tab all of which facilitates the easy opening of the cans without employing a can opener. Cans and EOE were thoroughly washed before use to remove adhering impurities and dried well to remove traces of water

Easy-open-ends of TFS cans: The easy open ends (EOE) have been developed for food cans. The easy open end has the convenience of opening the can easily using a finger. The easy open end can be made by TFS and thickness of $0.28 \mathrm{~mm}$; it consists of two parts, the lid and the tab. The tab is secured onto the lid by means of integral rivet. By pulling the tab, the whole central panel can be removed. In EOE, TFS is pre-punctured to provide full aperture, which is sealed by an adhesive strip of metallised polyester film.

\section{Oil}

Double refined sunflower oil was used for the curry preparation.

\section{Salt and other curry ingredients}

Salt of edible quality confirming to IS: 594-1962 was used. All other ingredients used for the curry preparations were of good quality, food grade and fit for human consumption.

\section{Prepared fish curry}

The curry of fish, prawn, crab and mussel were prepared as in Ist chapter and evaluated using standards testing condition and TFS cans were used for packing. The cans were thoroughly washed to remove adhering impurities and dried well to remove traces of water. Before filling the cans, a thermocouple was fixed at about one third from bottom of the can to record the core temperature.

\section{Analysis of can}

Determination of water capacity (IS: 6093-1970): Two holes of 3-4 mm diameter were drilled about $5 \mathrm{~cm}$ apart as close as possible to the countersink, from inside surface outwards on a can end. This was attached by double seaming on the other end of the can body. The can was weighed to the nearest $1 \mathrm{~g}$ and the container was filled with water at $27^{\circ} \mathrm{C}$ employing a narrow water jet through one of the holes. Surplus water on the outside of the can was removed using a blotting paper and the filled can was weighed to the nearest $1 \mathrm{~g}$. The difference between the weights was noted and to this $0.45 \%$ of the value was added. This represents the capacity in milliliters.

Air pressure test (IS: 9396-1979): This test was performed to determine the pressure holding capacity of the cans and to check for any leakage through the double seam. The cans were pierced with a piercing type of pressure gauge and then air was pumped inside using a foot operated pump until any distortion of the can or any leakage through the double seam area was noticed. The double seamed can was immersed in boiling water for $5 \mathrm{~min}$ prior to the test.

Determination of Vacuum (IS: 3336-1968): The vacuum in the can was determined with a vacuum gauge of the piercing type.

Test for coating perfection: The perfection of the PET coating was analyzed using the Lacquer Coating Breakage (LCB) detector. The can was filled with $10 \%$ brine and attached to the LCB detector in such a way that one of the electrodes was in contact with the edge of the flange where the base metal was exposed and the other electrode was dipped in the brine. Presence of any discontinuity in the coating allows the circuit to complete which was indicated by light and audio indicators.
Sulphide blackening test: Resistance of cans to sulphide blackening was analyzed following the cysteine test. For this, cans were filled with the test solution consisting of $0.5 \mathrm{~g}$ of cysteine chloride in 1liter of buffer solution (3.56 g KH2 PO4 and NA2H PO4. 2 H2O in 1 liter of distilled water). Filled cans were double seamed and retorted for $30 \mathrm{~min}$ at $125^{\circ} \mathrm{C}$. They were then left to cool down at room temperature for $24 \mathrm{hrs}$ and were opened and evaluated for any blackening [6].

Test for delamination of PET coating: The polymeric coating of TFS can was subjected to delamination test using various organic solvents like acetone, carbon tetra chloride, chloroform, diethyl ether, ethyl acetate, $n$-heptane, methanol, and petroleum ether. Panels of 1 X 1 $\mathrm{cm}$ size were taken and immersed in organic solvents. They were taken out after $24 \mathrm{hrs}$ and examined for any delamination of the PET coating. When there was no peeling they were kept immersed for another 12 hrs. The panels were taken out and heated in water bath for few minutes and examined for delamination of the coating

Test for thickness of PET coating: The PET coating was first delaminated from the base metal by immersing in chloroform for 24 hrs. It was then dried in air at room temperature. The dried material was analyzed for its thickness using a digital micrometer.

Test for suitability of can for processing at different temperature and pressure: The cans were processed at different temperatures and pressures of 115 (10 lbs), 121.1.1 (15 lbs), $126(20 \mathrm{lbs})$ and $130^{\circ} \mathrm{C}(25$ lbs) in a pilot scale retort of model 24 rotary retorting systems (John Fraser and sons Ltd, UK. Model.No.5682) to determine its ability to withstand different processing conditions.

Test for food contact application: Suitability of the can for food contact application was found out by determining the water extractives at $121.1^{\circ} \mathrm{C}$ for $2 \mathrm{hrs}$ and soluble chloroform extractives as per the methods of FDA (2003). The cans were filled with $200 \mathrm{ml}$ of hot glass distilled water and immediately heat-sealed. The sealed cans were heat processed at $121.1^{\circ} \mathrm{C}$ for $2 \mathrm{hrs}$. After processing the processed water was transferred into clean beakers and evaporated up to $50 \mathrm{ml}$. The contents of the beaker were transferred into another clean pre weighed tarred platinum dish and evaporated to dryness. After cooling the weight of the dish was again taken to the nearest $0.1 \mathrm{mg}$ to find out the amount of water extractives. To those dishes containing water extractives $50 \mathrm{ml}$ of chloroform was added to dissolve all the chloroform extractives. The contents were filtered and evaporated to dryness in a clean pre weighed tarred platinum dish. After drying the weight of the dish was again taken to the nearest $0.1 \mathrm{mg}$ to determine the amount of chloroform extractives.

Test for seam integrity: The seam integrity of the polymer coated tin free steel cans was analysed following the cut out analysis [7] and using the semi-automatic Double seam analyzer (Quality by Vision, Model Sea Metal 9000M, Israel). For cut out analysis, double seamed cans were selected at random and three equidistant points were marked on the circumference of the seam of the can. Using a micrometer, the Seam length (L), Seam thickness (Ts), Body hook, Cover hook, Body plate thickness $(\mathrm{Tb})$, Cover plate thickness $(\mathrm{Tc})$, were measured.

From these parameters, the \% overlap was calculated using the formula.

$$
\% \text { Overlap }=\frac{\mathrm{BH}+\mathrm{CH}+1.1 \mathrm{tc}-\mathrm{L}}{\mathrm{L}-(2.2 \mathrm{tc}+1.1 \mathrm{tb})}
$$

Where

$\mathrm{BH}=$ Body hook length 


\section{$\mathrm{CH}=$ Cover hook length \\ $\mathrm{tc}=$ Cover plate thickness \\ $\mathrm{tb}=$ Body plate thickness \\ $\mathrm{L}=$ Seam length.}

For the purpose of seam analysis using the double seam analyzer, double seamed cans were selected at random and three cut sections were made on the double seam one after the other using the twin blades of the seam saw which are rotating at a speed of about $500 \mathrm{rpm}$. The cut width is $12.9 \mathrm{~mm}$, which accurately fits to the camera of seam analyzer. The double seam parameters such as Seam length (L), Seam thickness (T), Body hook (BH), Cover hook ( $\mathrm{CH})$, Body thickness (tb), End plate thickness $(\mathrm{tc})$ etc were measured using the seam analyzer Sea Metal 9000M.

\section{Thermal processing analysis}

Preparation of test cans: Adequate number of test cans was prepared to trace the thermal history during the heating and cooling phases of the canning operation. For this the cans were perforated from the side by using the can punch which can form holes through which the packing gland can be inserted into the can. The perforation was done in such a way that the thermocouple tip was pointed towards the centre of the can at one third heights from the bottom which is recognized as the slowest heating point. The packing gland was then tightly screwed into the can body with the rubber gasket which helps to forming leak proof joint.

\section{Standardisation of optimum process parameters for ready to eat fish products in polymer coated tin free steel cans}

Heat penetration studies were conducted with the purpose of standardizing the optimum process condition for various ready to eat fish products in tin free steel cans. The heat penetration studies of fish, shrimp, crab and mussel curry were carried out separately by thermal processing at $121.1^{\circ} \mathrm{C}$ to $\mathrm{F}_{\mathrm{o}}$ values of 7,8 and 9 and 6,7 and 8 respectively in a stationary retort. In both cases, about $240 \mathrm{~g}$ of product was packed in washed and dried $6 \mathrm{Oz}$ polymer coated easy open-end TFS cans, maintaining headspace of $10 \mathrm{~mm}$. During can filling, care was taken to avoid the curry from contaminating the sealing area of the cans. Adequate numbers of test cans were prepared by fixing with thermocouple glands at about one third height from the bottom of the can with the tip of the gland pierced into the core of the meat. The cans were exhausted under steam in an exhaust box for $10 \mathrm{~min}$ and immediately double seamed in a double seaming machine. The sealed cans of fish, shrimp, crab and mussel curry were divided into 3 batches and were loaded inside the retort (John Fraser and sons Ltd, UK. Model.No.5682) separately on perforated stainless steel trays. The thermocouple probes were attached to the thermocouple glands that were already attached to the test cans. The lead wires from the thermocouples were attached to the Ellab data recorder (Model TM 9608, Ellab A/S). Three test cans were employed for each trial run of each product. Care was taken to maintain the initial product temperature at $35^{\circ} \mathrm{C}$. Fish, shrimp, crab and mussel curry was processed at $121.1^{\circ} \mathrm{C}$ to three different Fo values of 7,8 and 9 min while conducted. The cans were cooled rapidly by spraying water under pressure to a core temperature of $40^{\circ} \mathrm{C}$ so as to prevent the proliferation of thermophiles and the product from getting overcooked. The cooling water was maintained with constant chlorine residual level of $2 \mathrm{mg} / \mathrm{L}$. Graves et al. [8] recommended a residual chlorine level of $1-3 \mathrm{mg} / \mathrm{L}$ to maintain bacterial control in cooling water. The thermal history of the retort and the test cans during the entire thermal process operation was collected at every $30 \mathrm{sec}$ using Ellab data recorder (Model TM 9608, Ellab A/S) evaluated as described below heat penetration data. The cans were then dried, labeled and stored. The cans were stored at room temperature for about 15 days and then subjected for the analysis of commercial sterility, instrumental colour, texture, shear force and sensory parameters for the selection of optimum process conditions.

\section{Storage study}

Canned foods are one of the stable foods. Hayakawa et al. (1978) [9] reported that quality of canned products gradually deteriorates during storage, especially when it is stored at relatively higher temperatures. Since canned foods are stored for variable time periods before being consumed, it would be interesting to know the storage life of these products in orders to establish its expiry date. Ready to eat fish, shrimp, crab and mussel curries were prepared and processed in large scale according to the chosen $\mathrm{F}_{\mathrm{o}}$ values and kept for storage studies at room temperature $\left(30 \pm 2^{\circ} \mathrm{C}\right)$ during which samples were taken on monthly basis and were analyzed for instrumental colour, TPA, shear force, TBA, $\mathrm{pH}$ and sensory characteristics for a period of one year. Since ready to eat products are consumed without any further preparation, parameters like colour and appearance play vital role in the acceptance of the product.

\section{Analysis of Curry Meat}

\section{Physiochemical parameters}

pH (IS: 2168-1971): $5 \mathrm{~g}$ of the sample was dissolved in $10 \mathrm{ml}$ of distilled water and $\mathrm{pH}$ was measured by using $\mathrm{pH}$ meter.

Instrumental colour: The $\mathrm{L}^{\star}, \mathrm{a}^{*}$ and $\mathrm{b}^{*}$ or CIE Lab colour values of the samples were analyzed using Hunter lab colorimeter (Model No: Miniscan-XE plus, Hunter associates laboratory, Virginia, USA). Fish, shrimp, crab, mussel curry muscle pieces were finely homogenized in a food homogenizer (Kenstar Kitchen Appliances India Limited, Aurangabad, India) and loaded inside the sample holder while all the four curry meat was made free of skin and bones before homogenising.

Texture profile attributes: The texture profiles of samples were analyzed using a food texture analyzer (model LRX Plus, Lloyds Instruments, Hampshire, U.K.) and Nexygen software (Lloyds Instruments). The sample was placed on a flat platform and was subjected to double compression by a cylindrical probe with a $50 \mathrm{~mm}$ diameter. The test was conducted at a speed of $12 \mathrm{~mm} / \mathrm{min}$ using a $50-\mathrm{N}$ load cell. The sample was allowed for a double compression of $40 \%$ with a trigger force of $0.5 \mathrm{~kg}$ and various textural parameters like hardness1, hardness 2 , cohesiveness, springiness, gumminess and chewiness were determined.

\section{Results and Discussion}

In the present study (Table 1) indigenous polymer coated Tin Free Steel cans was analyzed for their suitability for thermal processing and storage of fish and fishery products following standard methods. These cans had water holding capacity of $500 \mathrm{ml}$ and were found to withstand internal air pressure of 30 psi for about 15 seconds without undergoing any bulging or leakage through the double seam area. Fish and fishery products are usually processed at $121.1^{\circ} \mathrm{C}$ with corresponding pressure of 15 psi cans were found to retain their original shape without any distortion, and they did not require any overpressure during processing. The cut out analysis of polymer coated tin free steel cans showed that the base plate and end plate have thickness of $0.19 \mathrm{~mm}(0.15 \mathrm{~mm}$ of base steel $+20 \mu$ PET coating on either side) and $0.28 \mathrm{~mm}$ (including PET 


\begin{tabular}{|l|l|}
\hline Parameters & Result \\
\hline Water holding capacity & $500 \mathrm{ml}$ \\
\hline Air pressure Test & Withstands $30 \mathrm{psi} / 15$ seconds \\
\hline Base plate and End plate thickness & $0.19 \mathrm{~mm} / 0.28 \mathrm{~mm}$ \\
\hline Overlap percentage & $63.3 \%$ \\
\hline Double seam Analysis & Analyzer SEAMetal $9000 \mathrm{M} /$ good \\
\hline Lacquer coating Testing & $97 \%($ LCB detector indicator) \\
\hline Sulphide stains (black discolouration) & 18 month/ Rust- Free \\
\hline Delamination of PET coating & 36 hrs of immersion no peeling \\
\hline Thickness of PET coating & $20 \mu$ uniform thickness \\
\hline Water soluble extractive value (TFS) & $6.9 \mathrm{ppm}$ \\
\hline Chloroform soluble extractive value & $0.64 \mathrm{ppm}$ \\
\hline
\end{tabular}

Table 1: Physical properties of indigenous TFS can

\begin{tabular}{|l|l|}
\hline Tests & Result \\
\hline Body plate thickness $(\mathrm{tb})$ & $0.193 \mathrm{~mm}$ \\
\hline Cover plate thickness $(\mathrm{tc})$ & $0.287 \mathrm{~mm}$ \\
\hline Body hook length $(\mathrm{BH})$ & $1.480 \mathrm{~mm}$ \\
\hline Cover hook length(CH) & $1.982 \mathrm{~mm}$ \\
\hline Seam length(L) & $2.681 \mathrm{~mm}$ \\
\hline Seam thickness(T) & $1.423 \mathrm{~mm}$ \\
\hline Free space(G) & $0.183 \mathrm{~mm}$ \\
\hline Percentage Overlap & $63.3 \%$ \\
\hline Percentage body hook butting & $70.42 \%$ \\
\hline
\end{tabular}

Table 2: Cut out analysis of TFS cans.

\begin{tabular}{|l|l|l|l|l|}
\hline Months & fish curry & shrimp curry & crab curry & mussel curry \\
\hline 0 & $9.08 \pm 0.00$ & $8.68 \pm 0.22$ & $8.75 \pm 0.29$ & $8.50 \pm 0.00$ \\
\hline 2 & $8.51 \pm 0.22$ & $8.49 \pm 0.25$ & $8.63 \pm 0.00$ & $8.25 \pm 0.28$ \\
\hline 4 & $8.37 \pm 0.22$ & $8.35 \pm 0.28$ & $8.50 \pm 0.28$ & $8.13 \pm 0.25$ \\
\hline 6 & $8.21 \pm 0.24$ & $8.22 \pm 0.25$ & $8.25 \pm 0.25$ & $7.74 \pm 0.24$ \\
\hline 8 & $8.01 \pm 0.25$ & $8.12 \pm 0.00$ & $8.00 \pm 0.25$ & $7.62 \pm 0.26$ \\
\hline 10 & $7.76 \pm 0.25$ & $7.89 \pm 0.28$ & $7.88 \pm 0.25$ & $7.58 \pm 0.22$ \\
\hline 12 & $7.16 \pm 0.28$ & $7.72 \pm 0.28$ & $7.50 \pm 0.27$ & $7.50 \pm 0.28$ \\
\hline 14 & $7.35 \pm 0.24$ & $7.61 \pm 0.27$ & $7.50 \pm 0.25$ & $7.50 \pm 0.28$ \\
\hline 16 & $7.28 \pm 0.31$ & $7.43 \pm 0.47$ & $7.38 \pm 0.29$ & $7.13 \pm 0.25$ \\
\hline 18 & $7.10 \pm 0.41$ & $7.25 \pm 0.28$ & $7.38 \pm 0.25$ & $7.09 \pm 0.25$ \\
\hline 20 & $7.02 \pm 0.53$ & $7.13 \pm 0.30$ & $7.20 \pm 0.00$ & $6.90 \pm 0.00$ \\
\hline 22 & $6.94 \pm 0.44$ & $6.98 \pm 0.47$ & $6.98 \pm 0.25$ & $6.93 \pm 0.28$ \\
\hline 24 & $6.75 \pm 0.00$ & $6.86 \pm 0.32$ & $6.76 \pm 0.27$ & $6.75 \pm 0.30$ \\
\hline
\end{tabular}

*Values are mean \pm standard deviation of 10 observations

Table 3: Sensory evaluation (Overall Acceptability) of thermal processed fishery products in different curries stored at ambient temperature.

coating on either side), respectively. The percentage overlap of polymer coated tin free steel cans is $63.3 \%$ which is higher than the required value of $45 \%$. The results of double seam parameters done by using manual method was compared with that of the results by using the semi automatic double seam analyzer Sea Metal 9000M and good agreement could be achieved between the two methods. Testing for lacquer coating integrity of polymer coated TFS cans using LCB detector indicated that $97 \%$ of the tested cans had polymer coating free from any defects. The cans were found to be resistant to sulphide blackening which indicates the perfection of the polymer coating.

The indigenous polymer coated TFS cans was compared with other commercially available cans and its suitability for thermal processing and storage of fish and fishery products. All the containers were found to have percentage overlap which is much higher than the prescribed limit. Upon testing for pressure holding capacity, both tin and TFS cans were found to withstand an internal air pressure up to $30 \mathrm{psi}$ without showing any bulging for the prescribed period of 15 seconds.
Test for lacquer coating integrity using LCB detector indicated that the polymer coating of TFS cans are superior. On the contrary, about $97 \%$ of the TFS cans tested were found to pass the LCB test indicating the perfection of the polymer coating. The extractive value for TFS cans using distilled water as stimulant was $6.9 \mathrm{ppm}$, respectively whereas the chloroform soluble extractives for the same were $0.64 \mathrm{ppm}$ respectively. The suitability TFS of cans for storage of fishery products showed that tin cans developed rusting on internal and external surface even at the sixth month of storage. TFS cans were free from any signs of rusting even at the end of 12 months and it extended up to 18 month storage period. TFS cans exhibited excellent content releasing property while fish pieces were found attached to the walls of tin and aluminium cans. Development of black discolouration could be noted on the inner surface of tin cans while TFS cans were free from any sulphide stains on storage. The raw materials used for the development of ready to eat thermally processed fish products were found to be in fresh condition. The values for various biochemical and microbiological parameters of the raw materials were well within the limits. Based on the analysis of commercial sterility, instrumental colour, texture and sensory parameters, Fish, shrimp, crab and mussel curry processed to Fo $7 \mathrm{~min}$ with total process time of $44.0 \mathrm{~min}$ and cook value of $91.1 \mathrm{~min}$ was found to be ideal and was selected for storage study Pushparajan et al. (2012) [10].

Fish, shrimp, crab and mussel curry thermally processed in indigenous polymer coated TFS cans were found to be acceptable even after one year of storage at room temperature based on the analysis of various sensory and biochemical parameters. The study indicated that the suitability of indigenous polymer coated TFS cans for processing at high temperature and pressure. The cook value was found to exhibit an inverse relationship with processing temperature $(\mathrm{p}<0.05)$ and was maximum at $115^{\circ} \mathrm{C}$ and minimum at $130^{\circ} \mathrm{C}$. The cut out analysis of TFS cans are given in table 2 . The percentage for body hook butting was $70.42 \%$ and percentage of overlap was $63.3 \%$. This result indicates that the efficiency was perfectly in order and the values were well above the minimum prescribed limits [11]. Sensory evolution of fishery products caned in TFS cans was carried out at regular intervals of 2 months. Changes in overall acceptability of products during storage at ambient temperature are presented in table 3 . The fishery products were acceptable even after 24 months of storage at ambient temperature. The initial overall acceptability score of about 8.75 and it was gradually reduced to around 6.78 .

The heat penetration data was plotted on an inverted semi log paper with product Temperature deficit (RT-CT) on vertical log scale (Y-axis) against time on the linear horizontal scale (X-axis) as described in NCA manual (1968) [12]. The lag factor of heating (jh), lag factor of cooling (jc), slope of heating curve ( $\mathrm{fh}$ ), time in minutes for sterilization at retort temperature $(\mathrm{U})$, Temperature deficit $(\mathrm{g})$, Cooking value $(\mathrm{Cg})$, Process time (B) and Total process time (TB) were determined. Cooling curve was plotted and cooling process parameters were determined as described by Ramaswamy and Singh [13]. Using these parameters the

\begin{tabular}{|l|l|l|l|l|l|l|l|l|}
\hline Filling medium & jh & jc & fh & U & g & Cg(min) & B(min) & TB(min) \\
\hline Fish curry & 1.134 & 1.26 & 29.15 & 2.54 & 0.98 & 121.1 & 50.30 & 53.60 \\
\hline Shrimp curry & 1.084 & 1.09 & 14.58 & 1.81 & 1.81 & 69.73 & 46.42 & 50.48 \\
\hline Crab curry & 1.12 & 1.08 & 6.02 & 2.42 & 2.73 & 108.2 & 35.70 & 40.43 \\
\hline Mussel Curry & 1.11 & 1.07 & 24.48 & 3.00 & 1.49 & 121.1 & 50.81 & 54.72 \\
\hline
\end{tabular}

(jh)lag factor of heating, (jc)lag factor of cooling, (fh)slope of heating curve, (U) time in minutes for sterilization at retort temperature, (g) Temperature deficit, (Cg) Cooking value (B)Process time, (TB)Total process time.

Table 4: Heat penetration data of thermally processed different fish curries filling mediums in polymer coated TFS cans. 


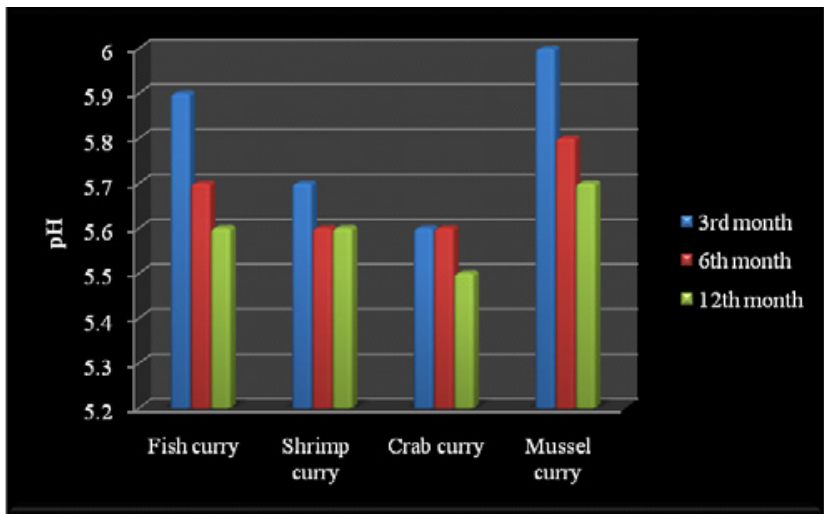

Figure 1: Change in the $\mathrm{pH}$ of fish, shrimp, crab and mussel curries during storage at room temperature.

\begin{tabular}{|l|c|c|}
\hline Various curry & $\mathbf{F}^{\circ}$ Value & $\begin{array}{c}\text { Shelf life at ambient } \\
\left.\text { temperature } \mathbf{( 2 8} \mathbf{\pm} \mathbf{2}^{\mathbf{}} \mathbf{C}\right)\end{array}$ \\
\hline Fish curry & 10 & More than 18 month \\
\hline Shrimp curry & 10 & More than 18 month \\
\hline Crab curry & 9 & More than 18 month \\
\hline Mussel curry & 9 & More than 18 month \\
\hline
\end{tabular}

Table 5: Shelf life of different fish curry products processed in TFS can.

process time (B) was calculated according to mathematical method [14]. The total process time was calculated by adding $58 \%$ of come up time (CUT) to B (Table 4). The Sterilization Value (F value) recommended for the thermal processing of fish products ranges from 5-20 [15]. In the present study $\mathrm{F}_{\mathrm{o}}$ was taken as optimum process required and all the products were processed to $\mathrm{F}_{\mathrm{o}} 10$. It was observed that the products processed in different filling curry medium to $\mathrm{F}_{\mathrm{o}}$ value of 10 were commercially sterile.

Storage analysis of Hydrogen ion concentration $(\mathrm{pH})$ is of relevance in the case of muscle foods as it affects its texture. In case of heated fish muscle, an exceptionally high effect of $\mathrm{pH}$ on the toughness was reported at the range 5.7, 6.7 [16]. In the $\mathrm{pH}$ of curries during storage is summarised. It can be seen that the initial $\mathrm{pH}$ of fish, shrimp, crab and mussel curries are 5.9, 5.7, 5.6 and 6.0 respectively indicating that it is towards the acidic side. The acidic nature of the product can be attributed to the acidity contributed by the curry ingredients like tomato. During storage, the $\mathrm{pH}$ of the products was found to exhibit a decreasing trend. On the $6^{\text {th }}$, month of storage, the $\mathrm{pH}$ of fish, shrimp, crab and mussel curries were found between 5.7,5.6, 5.6 and 5.8 respectively which are significantly lower as compared to initial values. On the $12^{\text {th }}$ month of storage, the $\mathrm{pH}$ of fish, shrimp, crab and mussel curries were 5.6, 5.6, 5.5 and 5.7 respectively (Figure 1). The results of present study agrees with the findings of Mallick et al. [17] who reported a decreasing trend in $\mathrm{pH}$ in case of north Indian style rohu curry stored in cans after 6 months of storage at room temperature at $37 \pm 2{ }^{\circ} \mathrm{C}$. Mohan (2004) reported a slight reduction in the $\mathrm{pH}$ of kuruma shrimp upon storage in both retort pouch and aluminium cans [18].

The instrumental analysis of colour values of all four sample of fish, shrimp, crab and mussel curries had initial $L^{\star}$ value of 16.85 . This low lightness value was due to the addition of curry ingredients. With storage the $\mathrm{L}^{\star}$ value exhibited significant reduction in the case of all the four samples. The $L^{*}$ value of fish, shrimp, crab and mussel curries at the end of storage study was $14.85,15.6,14.17$ and15.71 respectively. The initial $\mathrm{a}^{*}$ value of fish, shrimp, crab and mussel curries are 8.23, 8.19, 8.4 and 8.36 respectively [10]. The higher $\mathrm{a}^{\star}$ value can be attributed to the addition of tomato and red chilly as curry ingredients. The $\mathrm{a}^{*}$ value was found to increase slightly with storage and was 9.39, 9.31, 9.4 and 8.85 at the end of storage study. The $b^{*}$ value of fish, shrimp, crab and mussel curries on the first month of storage was 18.97, 19.21, 18.20 and 15.87 respectively which storage does not change appreciably. The $b^{*}$ value at the end of 12 month storage was 19.18, 19.82, 19.55 and 15.92 for fish, shrimp, crab and mussel respectively.

Shelf life of fish, shrimp, crab and mussel curries medium processed in the TFS cans are presented in the table 5 . All products showed a shelf life of more than 18 months at ambient temperature and were commercially sterile. The processed fishery products were found to be sterile and acceptable even after a period of 12 months at ambient temperature $[19,20]$. The results of the present experiments showed that the polymer coated TFS cans are suitable for processing fishery products [17]. Polymer coated TFS cans was found to withstand all the conditions of thermal processing. The TFS cans which are now available in India can be used for thermal processing of various fish products as a substitute to other packs. The present studies suggest that the indigenous polymer coated TFS cans are suitable for thermal processing and storage of various fish and fishery products. The Indigenous polymer coated TFS cans was found to be superior over conventional tin and aluminium cans. The ready to eat fish, shrimp, crab and mussel curries processed in TFS cans could be stored at room temperature with acceptable qualities for more than one year. The study also indicated that indigenous polymer coated TFS cans with easy open ends can be a viable alternative to the conventional tin and aluminium cans. The fishery industry can utilize these cans for processed ready to eat fish and shellfish products for both domestic and export markets. This will help in reviving the canning industry in India.

\section{References}

1. Sablani SS, Ramaswamy HS (1996) Particle heat transfer coefficients under various retort operating conditions with end-over-end rotation. J Food Pro Enginee 19: 403-424.

2. Barbeiri G, Milanes G, Rosso S (1970) Industria Conserve, Food Additive Contamination 45: 58.

3. Crisan EV, Sands A (1975) Microflora of four fermented fish sauces. Appl Microbiol 29: 106-108.

4. Naresh R, Mahadeviah M, Gowramma RV, Swamy BA (1989) Chromium coated steel plate as an alternative to tin plate for canning food products. Journal of Food Science Technology 17: 283-286.

5. Gupta V, Nagar R (2010) Effect of cooking, fermentation, dehulling and utensils on antioxidants present in pearl millet rabadi - a traditional fermented food. Journal of Food Science and Technology 47: 73-76.

6. Anon (1977) Anticipator-developing a safety system for industrial hazards Measmnt Control 10: 51.

7. Balachandran KK (2003) Fish canning- Principles and practices. Centra Institute of Fisheries Technology (ICAR), Cochin, India.

8. Graves RR, Lesniewski RS, Lake DE (1977) Bacteriological quality of cannery cooling water. Journal of Food Science 42: 1280-1285.

9. Hayakawa KI, Timbers GE, Stier EF (1978) Sensory qualities of selected canned foods subjected to short term storage. Journal of Food Science 4: 944947.

10. Pushparajan N, Soundarapandian P, Varadharajan D (2012) Recipies Preparation of Some Commonly Available Fish and Shellfishes.In:Open Access Scientific Reports, OMICS Publishing Group.

11. Gopakumar K (1993) Retort pouch processing. In: K. Gopakumar (Edn.), Fish packaging technology, materials and methods. Concept publishing company, New Delhi.113-132.

12. National Canners Association (1968) Laboratory manual for Food Canners and Processors.In: AVI Publishing Co. p, USA, pp: 204-219. 
Citation: Pushparajan N, Varadharajan D, Soundarapandian P (2013) Feasibility of Fish and Shellfish Curries Stored in Indigenous Polymer Coated Tin Free Steel Cans. J Aquac Res Development 4:165 doi:10.4172/2155-9546.1000165

Page 6 of 6

13. Ramaswamy HS, Singh RP (1997) Sterilization process engineering. In: Valentas KJ, Rostein E, Paul Singh R, (eds) Handbook of Food Engineering Practice CRC Press, New York, USA.

14. Stumbo CR (1973) Thermobacteriology in Food Processing. 3rd ed, Academic Press Inc, New York \& London: 236.

15. Frott R, Lewis AS (1994) Canning of meat and fish products, Chapman Hall London, UK: 202

16. Dunajski E (1979) Texture of fish muscle. J Text Stud 10: 301-318. Journal of Food Science 4: 944-947.

17. Mallick AK, Srinivasa Gopal TK, Ravishankar CN, Vijayan PK (2006) Canning of Rohu (Labeo rohita) in North Indian Style Curry Medium Using Polyester- coated Tin Free Steel Cans. Food Science and Technology Institute 12: 539545 .

18. Mohan CO (2004) Thermal Processing of Prawn Kuruma (Penaeus indicus) in Retortable Pouch and Aluminium Can. MFSC Thesis, Central Institute of Fisheries Education, Mumbai, India.

19. Bindu J, Srinivasa Gopal TK, Unnikrishanan Nair TS (2004) Ready to eat mussel meat processed in retort pouches for retail and export markets. Packaging Technology and Science 17: 113-117.

20. Bindu J, Ravishanker, Dinesh CN, Mallick K, Gopal TKS (2011) Hea penetration characteristics and shelf life of Ready to serve mahseer curry in opaque reportable pouches. Fish Technology 48: 141-148. 